\title{
Establishing an in vitro production program for buffalo embryos (Bubalus bubalis) in Colombia
}

\author{
Establecimiento de un programa de producción in vitro de \\ embriones bufalinos (Bubalus bubalis) en Colombia
}

\author{
Felipe Gamarra $\mathrm{P}_{1}^{1} \mathrm{MV}$, Viviana Rendón $\mathrm{V}^{1}{ }^{1} \mathrm{MV}$, Aldemar Chávez $\mathrm{R},{ }^{1} \mathrm{MVZ}$, \\ Leonardo Perez S, ${ }^{1}$ MVZ, Walter Cardona-Maya, ${ }^{2}$ Ph.D, Jesús Berdugo G, ${ }^{3 *}$ M.Sc.
}

\begin{abstract}
${ }^{1}$ Genescol S.A. Carrera 17 \# 58-60 Autopista Palenque-Chimita, Girón, Santander, Colombia. 2Universidad de Antioquia. Facultad de Medicina, Grupo Reproducción, Carrera 53 \# 61-30, Laboratorio 534, Medellín, Colombia. ${ }^{3}$ Universidad Nacional de Colombia. Facultad de Medicina Veterinaria y de Zootecnia, Grupo de Reproducción Animal y Salud de Hato, Carrera 45 No 26-85 Edif 561B. Bogotá, Colombia. *Correspondencia: jaberdugog@unal.edu.co
\end{abstract}

Received: March 2014; Accepted: November 2014.

\begin{abstract}
Objective. Evaluate the results of the standardization of the in vitro production program of buffalo embryos, using oocytes obtained by ultrasound guided oocyte puncture during the 2012 breeding season in Colombia. Materials and methods. Fifty seven buffalo females were selected for ultrasound guided transvaginal aspiration of follicles, oocytes were identified within follicular fluid, classified and transported to the laboratory and matured in vitro for 18 to 20 hours. Frozen semen of seven Mediterranean bulls were used, motile sperm was obtained using the Percoll technique and oocytes were inseminated with 2 million sperm $/ \mathrm{ml}$. Presumptive zygotes were cultured for 6 days, grade 1 embryos obtained were frozen using ethylene glycol. Embryos were transferred to females on day 5 during natural cycle. Results. 97 aspirations were performed on the 57 animals, in $8.2 \%$ of the aspirations no oocytes were found. 8 oocytes/aspiration were obtained. Of the 783 oocytes, $92 \%$ were classified as viable (721/783) and were fertilized. The cleavage and blastocyst rate were $23 \%$ and $19 \%$ respectively. 37 embryos were transferred and 11 pregnancies were obtained, confirmed by rectal palpation 60 days after transfer, with a pregnancy rate of $29.7 \%$. Conclusions. The results presented here are comparable with others in literature and shows the feasibility of producing in vitro embryos and pregnancies after the standardization of current protocols, with normal and sexed semen and transfer during natural cycle in buffalo.
\end{abstract}

Key words: Buffaloes, embryo, fertilization in vitro, reproduction (Source: MeSH).

\section{RESUMEN}

Objetivo. Evaluar los resultados de la estandarización de la técnica de producción in vitro de embriones de búfalo, a partir de oocitos obtenidos por punción folicular durante la estación reproductiva del 2012 en una hacienda en Cordoba, Colombia. Materiales y métodos. Cincuenta y siete búfalas fueron seleccionadas para aspiración transvaginal de folículos guiada por ultrasonido, los oocitos fueron identificados y madurados in vitro. Se utilizó semen congelado de 7 búfalos de la raza Mediterráneo para la fertilización in vitro. La fracción móvil fue separada en un gradiente de Percoll, los oocitos fueron inseminados con 2 millones de espermatozides $/ \mathrm{mL}$, los presuntos cigotos fueron cultivados por 6 días y los embriones grado 1 obtenidos fueron congelados utilizando etilenglicol. Posteriormente, 
los embriones fueron transferidos el día 5 post estro en búfalas en ciclo natural. Resultados. En las 57 búfalas, se realizaron 97 aspiraciones foliculares, no se obtuvieron oocitos en el $8.2 \%$ de los procedimientos. Se obtuvieron en promedio 8 oocitos por búfala en cada sesión de aspiración. Se recolectaron 783 oocitos de los cuales fueron clasificados como viables el 92\% (721/783), se obtuvo una taza de clivaje del $23 \%$ y de blastocistos del $19 \%$. De 37 embriones transferidos se obtuvieron 11 preñeces, confirmadas por palpación rectal a los 60 días postransferencia, obteniéndose una taza de preñez del $29.7 \%$ Conclusiones. Los resultados presentados en este trabajo son comparables con los de la literatura, en la cual se muestra cómo es posible obtener embriones de semen convencional y sexado, además de producir gestaciones con protocolos estándar de fertilización in vitro y transferencia en ciclos con celo natural adaptados para la especie.

Palabras clave: Búfalos, embrión, fertilización in vitro, reproducción (Fuente: MeSH)

\section{INTRODUCTION}

Buffaloes are an important species due to their great adaptability in extreme environmental conditions and for their production of milk and meat. Muñoz et al (1) reported for Colombia an average milk production at 270 days of $1096 \pm 275 \mathrm{~kg}$ and the production of fat and protein at 270 days was 7.4 y $5.0 \%$, respectively for lactation. For meat production, animals with increases of up to $1200 \mathrm{~g} /$ day are possible, which shows precocity, obtaining a final product low in fat and with a high protein content. Additionally, it has been accepted that buffaloes are more efficient than tractors in pulling conditions up to one ton and its benefits in crops have been shown, especially in palm oil (1).

Buffaloes belong to the Bovidae family, bovines, the Bubalus genus, and the species includes bubalis and carabaensis $(2,3)$. Raising buffalo in Colombia has experienced an exponential increase in the last 15 years, and based on vaccination records, Fedegán, the Colombian Cattle Federation, reported that 160.449 heads exist in the country, females making up $70 \%$ of the population (3). Present in Colombia is the Bulbalina race, from the species Bubalus bubalis, comprised of Murrah, Mediterranean and a crossbreed of the first animals that arrived in the country, called buffalypso. From the vaccination model some technologies have been attempted to apply, especially in the area of reproduction, without satisfactory results. In Colombia, improvement programs for the species are being developed, and although reproductive biotechnologies are known and have been applied for more than 10 years, they have not spread widely to breeders (3).

The results of transferring embryos on buffalo ranches have had discouraging results, especially programs involving multiple ovulation and embryo transferring (MOET). Drost (4) reviewed the Hindu experience, including 10 years of superovulation and embryo transferring, finding

\section{INTRODUCCIÓN}

Los búfalos son una especie importante por su gran adaptabilidad a condiciones medioambientales extremas y por producción de leche y carne. Muñoz et al (1) reportó para Colombia una media de producción de leche a los 270 días de 1096 275 kg y la producción de grasa y proteína a los 270 días fue de 7.4 y $5.0 \%$, respectivamente por lactancia. Para la producción de carne, se tienen animales con ganancias de hasta $1200 \mathrm{~g} /$ día, lo que demuestra su precocidad, obteniendo un producto final bajo en grasa y con alto contenido de proteína. Adicionalmente, se ha aceptado que los búfalos son más eficientes que el tractor en condiciones de tiro de hasta una tonelada y se ha demostrado sus bondades en los cultivos, especialmente en los de palma de aceite (1).

El búfalo pertenece a la familia Bovidae, bovino, del que existe el género Bubalus al que pertenecen las especies, bubalis y carabaensis $(2,3)$. La cría del búfalo en Colombia ha experimentado un incremento exponencial en los últimos 15 años, la Federación Colombiana de Ganaderos -Fedegánbasada en los registros de vacunación informó que en el país existen 160.449 cabezas, siendo hembras el $70 \%$ de la población (3). En cuanto a la variedad de razas Bubalinas existentes en Colombia, de la especie Bubalus bubalis, se encuentran la Murrah, Mediterráneo y cruzas de los primeros animales que llegaron al país y que se denominan bufalypso. Del modelo vacuno se han tratado de aplicar algunas tecnologías, especialmente en el área de la reprodución, sin resultados satisfactorios. En Colombia, se están construyendo programas de mejoramiento para la especie y aunque las biotecnologías reproductivas se conocen y se aplican desde hace más de 10 años, no están ampliamente difundidas entre los criadores (3).

Los resultados de la aplicación de la transferencia de embriones en los hatos bufalinos han tenido resultados desalentadores, especialmente aquellos programas de múltiple ovulación y transferencia de embriones (MOET). Drost (4), revisó la experiencia 
2.3 embryos per animal with a pregnancy rate of $15 \%$ and an embryo reabsorption rate of $35 \%$.

Given the low rate of obtaining embryos by MOET, the in vitro production of embryos (PIV) became an alternative to obtaining embryos in these programs. The first buffalo embryo born in vitro was reported in India in 1990. The PIV can considerably increase the amount of embryos obtained, whether it be by slaughterhouse ovaries or live buffaloes. The average oocytes per ovary in the case of slaughterhouse is from 0.43 to 0.70 in India vs 2.4 to 3.3 in Italy (5), but if they are obtained by means of follicular aspiration guided by ultrasound (OPU), this increased up to 2.25 oocytes/ovary (6). When compared with bovines, in spite of being philogenetically similar and having similar general reproductive conditions, buffaloes have some very important differences, among them the presence of less primordial follicles and the formation of gonads (7), in consequence less follicles at birth and less amount of follicles selected in the ovulatory cycle (8).

For many years the selection system in buffalo production has had a strong maternal influence, since the offspring of the best female buffalos are the ones chosen as reproducers, and for that reason transferring embryos is chosen as the technique to be applied. Colombian breeders should increase productivity and efficiency in order to take care of market demands, especially taking advantage of the fact that animal reproduction is very efficient when it is evaluated in terms of gestation, birth rate and animal development $(9,10)$.

With this information and the uncertainty of the results, at the end of 2008 (11) the technique of transferring embryos produced in vitro in Colombia began, with variable results. From this first experience the first animals were born in 2011 (12) which prompted an investigation group to establish an embryo production program in Colombia. The objective of this investigative study is to show the results obtained in in vitro production of buffalo embryos, report pregnancies during the 20122013 reproductive season, and discuss information obtained in global literature in order to apply this technology and make it a reality for the Colombian buffalo industry.

\section{MATERIALS AND METHODS}

Study site. This study took place from August 2012 and January 2013, on the Praga farm, in the Municipality Pueblo Nuevo, Córdoba, in the agroecological area of a Tropical Rain Forest (8'28'69" North 75¹6'54" West), altitude 60 meters above sea level, annual rainfall $1600 \mathrm{~mm}$.
Hindú de 10 años de superovulación y transferencia de embriones, encontrando 2.3 embriones por animal, con una tasa de preñez del $15 \%$ y una tasa de reabsorción embrionaria del 35\%.

Dada la baja tasa de obtención de embriones por MOET, la producción in vitro de embriones (PIV) se convirtió en una alternativa para la obtención de embriones en estos programas. El primer embrión bufalino nacido in vitro fue reportado en la India en 1990. La PIV puede incrementar considerablemente la cantidad de embriones que se obtienen, bien sea de ovarios de matadero o de búfalas vivas. El promedio de oocitos por ovario en el caso de matadero es de 0.43 a 0.70 en la India vs 2.4 a 3.3 en Italia (5), pero si se obtienen mediante aspiración folicular guiada por ultrasonido (OPU), esta se incrementa hasta 2.25 oocitos/ovario (6). Cuando se compara con vacunos, a pesar de ser tan cercanos filogenéticamente y de tener condiciones generales reproductivas similares, el búfalo tiene algunas diferencias que se vuelven muy importantes, entre ellas la presencia de menos folículos primordiales en la formación de las gónadas (7), en consecuencia menos folículos al nacimiento y menor cantidad de folículos seleccionados en el ciclo ovulatorio (8).

Por muchos años, en la producción con búfalos, el sistema de selección ha tenido una gran influencia materna, siendo escogidos como reproductores los hijos de las mejores búfalas, es por eso que la transferencia de embriones es la técnica de elección para ser aplicada. Los criadores colombianos deben incrementar su productividad y eficiencia con el fin de atender las demandas del mercado, especialmente aprovechar que la reproducción de los animales es muy eficiente cuando se evalúa en términos de gestación, natalidad y desarrollo de los animales $(9,10)$.

Con esta información y la incertidumbre de los resultados, a finales del 2008 (11), se inició la aplicación de la técnica de transferencia de embriones producidos in vitro en Colombia, obteniendo resultados variables, de esa primera experiencia nacieron los primeros animales en el 2011 (12), que llevaron al grupo de investigación al establecimiento de un programa de producción de embriones en Colombia. El objetivo del presente trabajo de investigación es mostrar los resultados obtenidos en la producción in vitro de embriones bufalinos e informar la obtención de preñeces durante la estación reproductiva 2012-2013 y discutir la información obtenida con la literatura mundial con el fin de hacer de la aplicación de esta tecnología una realidad para la industria bufalina Colombiana. 
Animals. 57 females, 8 buvillas and 49 multiple births with a minimum of 90 days postnatal were used, weight at $530 \mathrm{~kg}$ and corporal condition superior to 3.5 (scale of 1 to 5: $1=$ emaciated y 5 = obese).

Follicular suction. Before aspirating the oocytes, the perineal area was washed and disinfected, and epidural anesthesia was given by means of a $4 \mathrm{~mL}$ injection of xylocaine. The buffalos were aspirated by means of a 20 caliber needle guided by ultrasound, connected to a convex transvaginal sound by means of an echograph (Mindray model DP 2200). The aspiration system was washed constantly with a half TCM 199 with $25 \mathrm{mM}$ of hepes, supplemented with 100 USP/ $\mathrm{mL}$ of heparin, $10 \%$ bovine fetal serum and $1 \%$ penicillin and streptomycin solution (20000 UI and $20000 \mu \mathrm{g} / \mathrm{mL}$ ). The oocytes were aspirated by means of the union to a vacuum pump with $80 \mathrm{mmHg}$ and were collected in $50 \mathrm{~mL}$ test tubes with $0.4 \mathrm{~mL}$ of heparin (Liquemine, Roche ${ }^{\circledR}$ ) and identified and classified on the farm. Once identified, the oocytes were classified as $A$, $B, C$, and D (13), all the A, B and C oocytes were classified as viable and transported to the laboratory in the middle of maturation in an incubator at $37.5^{\circ} \mathrm{C}$ in a gassified environment, TCM 199 with $25 \mathrm{mM}$ hepes, supplemented with $0.3 \mathrm{mM}$ cysteine, $50 \mu \mathrm{M}$ cisteamine, $0.5 \mu \mathrm{g} / \mathrm{ml}$ $\mathrm{FSH}, 5 \mu \mathrm{g} / \mathrm{mL} \mathrm{LH}$ and $1 \mathrm{ug} / \mathrm{mL} 17 \beta$ estradiol (14). All of the structures sent were subjected to maturation, no rounded structures were sent, which apparently do not have cytoplasm.

Laboratory procedure. Unless explicitly mentioned, all the reagents for the culture preparation were from Sigma-Aldrich (Sigma Chemical Co, St Louis, Mo, USA).

Once at the laboratory, the oocytes were transferred to Petri dishes to continue maturation in groups of a maximum of 20 until the moment of fertilization at 20 hours post aspiration.

For fertilization frozen conventional and sexed semen from COFA (Centro Fecundacione Artificialle, Cremona, Italy). To prepare the spermatozoids, the percoll $90-45$ technique was used (15). Semen straws were thawed at $37^{\circ} \mathrm{C}$ for 30 seconds. Semen was placed in the upper part of the gradient, after centrifuging, the pellet was re-suspended to obtain a concentration between 1.5 to 2 million spermatozoids $/ \mathrm{ml}$ with fertilization and TALP modified, supplementing with $0.2 \mathrm{mM} / \mathrm{mL}$ penicilamin, $0.1 \mathrm{mM} / \mathrm{mL}$ hipotaurin and $0.01 \mathrm{mM} / \mathrm{mL}$ heparin. Fertilization was done in dishes with $50 \mu \mathrm{l}$ drops, a maximum of 20 oocytes, using specific reproducers programmed for each donator. They were

\section{MATERIALES Y MÉTODOS}

Sitio de estudio. El presente estudio se realizó entre agosto del 2012 y enero del 2013, en la hacienda Praga, localizada en el Municipio de Pueblo Nuevo, Córdoba, condición agroecológica de Bosque Húmedo Tropical ( $8^{\circ} 28^{\prime} 69^{\prime \prime}$ Norte $75^{\circ} 16^{\prime} 54^{\prime \prime}$ Oeste), altitud 60 m.s.n.m, régimen anual de lluvias 1600 $\mathrm{mm}$.

Animales. Fueron utilizadas 57 hembras, 8 buvillas y 49 multíparas con mínimo 90 días posparto, peso de $530 \mathrm{~kg}$ y condición corporal superior a 3.5 (escala de 1 a 5: 1 = emaciada y 5 = obesa).

Aspiración folicular. Previa a la aspiración de los oocitos, la zona perineal fue lavada y desinfectada, y se indujo anestesia epidural mediante la inyección de $4 \mathrm{~mL}$ de xilocaina. Las búfalas fueron aspiradas mediante el uso de una aguja calibre 20 guiada por ultrasonido, acondicionada a una sonda transvaginal convexa mediante ecógrafo (Mindray modelo DP 2200). El sistema de aspiración fue lavado constantemente con medio TCM 199 con 25 $\mathrm{mM}$ de hepes, suplementado con $100 \mathrm{USP} / \mathrm{mL}$ de heparina, $10 \%$ de suero fetal bovino y $1 \%$ de una solución de penicilina y estreptomicina (20000 UI y $20000 \mu \mathrm{g} / \mathrm{mL}$ ). Los oocitos aspirados mediante la unión a una bomba de vacío con $80 \mathrm{mmHg}$ fueron colectados en tubos de ensayo de $50 \mathrm{~mL}$ con $0.4 \mathrm{~mL}$ de heparina (Liquemine, Roche ${ }^{\circledR}$ ) e identificados y clasificados en la misma finca. Una vez identificados, los oocitos fueron clasificados en A, B, C, y D (13), todos los oocitos grado A, B y C fueron clasificados como viables y transportados al laboratorio en medio de maduración en una incubadora a $37.5^{\circ} \mathrm{C}$ en medio gasificado, TCM 199 con $25 \mathrm{mM}$ de hepes, suplementado con $0.3 \mathrm{mM}$ cystine, $50 \mu \mathrm{M}$ cisteamina, $0.5 \mu \mathrm{g} / \mathrm{ml} \mathrm{FSH}$, $5 \mu \mathrm{g} / \mathrm{mL}$ LH y $1 \mathrm{ug} / \mathrm{mL} 17 \beta$ estradiol (14). Todas las estructuras enviadas fueron sometidas a maduración, no se incluyeron algunas estructuras redondeadas, que aparentemente no tienen citoplasma.

Procedimiento de laboratorio. A menos que se mencione explícitamente, todos los reactivos para la preparación de los medios de cultivo fueron de la firma Sigma-Aldrich (Sigma Chemical Co, St Louis, Mo, USA).

Una vez en el laboratorio, los oocitos fueron transferidos a cajas de Petri, para continuar su maduración en grupos de máximo 20, hasta el momento de la fertilización a las 20 horas post aspiración.

Para la fertilización se utilizó semen congelado convencional y sexado, proveniente de la central italiana COFA (Centro Fecundacione 
cultured in the fertilization environment between 20 and 24 hours at $38.5^{\circ} \mathrm{C}$, in a $5 \%$ atmosphere of $\mathrm{CO}_{2}, 90 \%$ humidity.

Later the oocytes were denuded and the zygotes were taken to half culture, synthetic oviductal fluid (SOF) to which essential and nonessential amino acids and bovine seric albumin were added. The first environmental change was 4 days after the aspiration; due to the characteristics of the buffalo oocytes it is not possible to identify the quantity of blastomers in each structure and due to this, only the non-inseminated structures are removed. The second environmental change is done at day 6, when the first blastocysts can be observed. The formation of blastocysts begins on day 6 obtaining those that are the best quality and go to day 8, when they were frozen by means of the ethylene glycol slow freezing method (12) for direct transfer.

Some embryos were transferred to receptors in a natural cycle, day 6 post-estrum in the ipsilateral horn to the corpus luteum of this cycle's ovulation.

Statistical analysis. Data was shown with statistically descriptive values, in comparative cases the proportion comparison test was sued and a nonparametric correlation analysis was done between the variables, $p>0.05$ was considered statistically significant; GraphPad Prism 5 (GraphPad software, San Diego, CA) program was used.

\section{RESULTS}

Between July 2012 and January 2013, 97 follicular aspirations were performed on 57 animals, 49 multi-birth buffalos and 8 young cows. The age of the buffalos was on average 96 months with a range from 14.5 to 206 months. The general results of the program are presented in table 1 .

Of the 57 buffalos, 36 were only aspirated once. 97 aspirations were done in 8 procedures,

\begin{tabular}{lcccc}
\hline Table 1. Comparison between young cows and \\
$\begin{array}{l}\text { multiple birth cows within the parameters } \\
\text { described for production of in vitro embryos } \\
\text { in water buffalo. }\end{array}$ \\
$\begin{array}{l}\text { Young } \\
\text { cows }\end{array}$ & $\begin{array}{c}\text { Multiple } \\
\text { birth cows }\end{array}$ & Total & Valor of p \\
\hline Animals & 8 & 49 & 57 & - \\
Aspiration & 15 & 82 & 97 & No difference \\
Total & 95 & 688 & 783 & ND \\
Oocytes / aspiration & 6.3 & 11.1 & 8.07 & $<0.05$ \\
Viables & 89 & 632 & 721 & ND \\
Oocytes / aspiration & 5.7 & 10.2 & 7.4 & ND \\
Blastocyst at day 6-7 & 12 & 123 & 135 & $<0.05$ \\
\% of blastocysts at day & $13.30 \%$ & $18.30 \%$ & $19 \%$ & ND \\
6-7/ viable oocysts & & & & \\
\hline
\end{tabular}

Artificialle, Cremona, Italia). Para preparar los espermatozoides fue utilizada la técnica de percoll 90-45 (15). Las pajillas de semen fueron descongeladas a $37^{\circ} \mathrm{C}$ por 30 segundos. El semen fue colocado en la parte superior del gradiente, después de la centrifugación el pellet fue resuspendido para obtener una concentración entre 1.5 a 2 millones espermatozoides/ml con el medio de fertilización y medio TALP modificado, suplementado con $0.2 \mathrm{mM} / \mathrm{mL}$ penicilamina, 0.1 $\mathrm{mM} / \mathrm{mL}$ de hipotaurina y $0.01 \mathrm{mM} / \mathrm{mL}$ de heparina. La fertilización se llevó a cabo en cajas en gotas de $50 \mu \mathrm{l}$, con máximo 20 oocitos, utilizando reproductores específicos programados para cada donante. Se cultivaron en el medio de fertilización entre 20 y 24 horas, a $38.5^{\circ} \mathrm{C}$, en una atmósfera de $5 \%$ de $\mathrm{CO}_{2}, 90 \%$ de humedad.

Posteriormente, los oocitos fueron desnudados y los presuntos zigotos fueron llevados a medio de cultivo, fluido oviductal sintético (SOF) al que se le adicionan aminoácidos esenciales y no esenciales y albúmina sérica bovina. El primer cambio de medio fue el día 4 post aspiración; debido a las características propias de los oocitos bufalinos no es posible identificar la cantidad de blastómeros de cada estructura debido a esto, sólo se retiran las estructuras no fecundadas. El segundo cambio de medio se realizó el día 6, momento en donde se comienzan a observar los primeros blastocistos. La formación de blastocisto inicia a partir del día 6 obteniendo los de mejor calidad y van hasta el día 8 de estadio, momento en el que fueron congelados, mediante la técnica de congelación lenta en etilenglicol (12), para transferencia directa.

Algunos embriones fueron transferidos a receptoras en ciclo natural, el día 6 post estro en el cuerno ipsilateral al cuerpo lúteo de la ovulación de ese ciclo.

Análisis estadístico. Los datos se mostraron con valores de estadística descriptiva, en los casos de comparación se usó la prueba de comparación de proporciones y se realizó análisis de correlación no paramétrica entre las variables, se consideró significancia estadística un $p>0.05$, se utilizó el programa GraphPad Prism 5 (GraphPad software, San Diego, CA).

\section{RESULTADOS}

Entre julio del 2012 y enero del 2013, se realizaron 97 aspiraciones foliculares a 57 animales, 49 búfalas pluríparas y 8 buvillas. La edad de las búfalas fue en promedio 96 meses con un rango de 14.5 hasta 206 meses. Los resultados generales del programa se presentan en la tabla 1. 
no oocytes were obtained, the maximum of oocytes per aspiration was 35. 783 oocytes were recovered, of these 721 (92\%) were classified as viable and were used to produce embryos. 8.07 total oocytes/buffalo and 7.4 oocytes/viable per aspiration. No significant differences were found in the production of oocytes/buffalo during the season, with a range from 8 to 11 .

126 oocytes were fertilized with sexed semen and there were no significant differences in cleavage or in the production of embryos when compared with non-sexed semen, $20 \%$ and $17 \%$ respectively.

Of the oocytes fertilized on day 4171 (23\%) cleaved and on days 7 and 8 of the culture, $135(19 \%)$ reached the blastocyst stage; all the embryos were frozen with ethylene glycol for direct transfer.

1.35 embryos were obtained by aspiration with a variation from 0 to 7 . Of the 135 embryos obtained, $88(65 \%)$ became blastocysts on day 6 , and $47(35 \%)$ on day 7 . The production of embryos in the first aspiration in September 2012 was $10 \%$ and the last reported one in January 2013 was $20 \%$, a significant difference $(p<0.05)$.

In 11 female buffalos (11.3\%) in which at least one oocyte was recovered no embryos were obtained, these represented 67 oocytes, $29 \%$ of these suspected zygotes did not cleave, $56 \%$ reached the state of 2 cells and $15 \%$ went from 4 to 8 cells on day 4 but stopped developing.

Additionally, buffalos that had given birth produced more oocytes and embryos than the young cows, 11.1 vs. 6.3 oocytes/buffalo and $18.3 \%$ vs $13.3 \%$ buffalo blastocysts respectively $(p<0.05)$. Concerning embryo development, the young cow embryos reached the blastocyst state on day 7, greater proportion than the buffalos that had given birth ( $56 \%$ vs $14 \%$ ).

Finally 37 embryos were transferred from which 11 pregnancies were started $(29 \%)$, confirmed by rectal palpation 60 days after transfer.

\section{DISCUSSION}

This study presents for the first time in world literature the use of PIV of buffalo embryos and the transfer of frozen embryos during natural heat for production of high quality buffalos.
De las 57 bufalas, 36 fueron aspiradas solamente una vez. Se realizaron 97 aspiraciones, en 8 procedimientos no se obtuvieron oocitos, el máximo de oocitos por aspiración fue de 35 . Fueron recuperados 783 oocitos, de estos 721 (92\%) fueron clasificados como viables y se utilizaron para producción de embriones. Se obtuvieron 8.07 oocitos totales/búfala y 7.4 oocitos/viables por aspiración. No se encontraron diferencias significativas en la producción de oocitos/búfala durante toda la estación, con un rango de 8 a 11 .

Se fertilizaron 126 oocitos con semen sexado y no se obtuvieron diferencias significativas en el clivaje ni en la producción de embriones cuando se comparó con semen no sexado, $20 \%$ y $17 \%$ respectivamente.

De los oocitos fertilizados al día 4 clivaron 171 (23\%) y en los días 7 y 8 de cultivo alcanzaron el estado de blastocisto 135 (19\%); todos los embriones fueron congelados en medio con etilenglicol para transferencia directa.

Se obtuvieron 1.35 embriones por aspiración, con un variación de 0 a 7. De los 135 embriones obtenidos, 88 (65\%) se convirtieron en blastocistos en el día 6 y 47 (35\%) en el día 7 . La producción de embriones en la primera aspiración en septiembre del 2012 fue del $10 \%$ y en la última informada en enero 2013 fue del 20\%; siendo esta diferencia significativa $(p<0.05)$.

En 11 búfalas (11.3\%) en las que al menos se recuperó un oocito no se obtuvieron embriones, estos representaron 67 oocitos, $29 \%$ de estos presuntos zigotos no clivaron, el $56 \%$ alcanzaron el estado de 2 células y el 15\% llegó de 4 a 8 células al día 4 pero detuvieron su desarrollo.

Adicionalmente, las búfalas paridas produjeron más oocitos y embriones que las buvillas, 11.1 vs 6.3 oocitos/búfala y $18.3 \%$ vs $13,3 \%$ blastocistos búfala respectivamente $(p<0.05)$. En cuanto al desarrollo embrionario los embriones de buvilla llegan al estado de blastocisto el dia 7, mayor proporción que las búfalas paridas ( $56 \%$ vs $14 \%$ ).

Finalmente fueron transferidos 37 embriones de los que se obtuvieron 11 preñeces (29\%) confirmadas por palpación rectal el día 60 post transferencia.

\section{DISCUSIÓN}

En este trabajo se presenta por primera vez en la literatura mundial el uso del PIV de embriones bufalinos y la transferencia de embriones congelados durante un celo natural para la producción de búfalos de calidad superior. 
It is seen to be a safe and reproducible procedure, complications were only seen in $1.7 \%$ of the cases; an edema could be explained as the anaphylactic reaction to the epidural anesthesia used, which was resolved spontaneously. Post aspiration complications were not present, such as adherences.

It should be kept in mind that to obtain oocytes of young animals the size of the vaginal canal was a limiting factor, since the transducer could not be used on 7 young cows (data not shown), and it is probable that in very young animals the transducer would damage the vagina canal and these animals cannot be aspirated. It was also seen that 8 buffalos could not be aspirated for anatomic reasons due to a narrow vagina or adherences of the internal organs.

The rate for obtaining oocytes in this study was 8.07 oocytes/buffalo by aspiration, which is superior to that informed in Italy 2.3 (13), Brazil 4.1-6.7 (16.17) and 1.2 in India (18). A possible explication could be the fact that the aspirations were done during the reproductive season, while some of these authors sampled their study during the whole year. The viability of this study was superior $(92 \%)$ to that reported in literature $(44 \%, 45 \%),(16,18)$.

Neglia et al (19), suggest that the length of the needle and the suction system have a great influence in the quality of the oocytes found, indicating that the cells of the cumulus, poorly adhered, are detached during the aspiration process. For this study a short needle was used, that goes directly connected to the conduction system, which could explain the high viability of the oocytes obtained, even more when one of the principal parameters of classification of the oocytes are the grainy layers surrounding it.

Also, it is important to highlight that when evaluating the oocytes there are very few that can be classified as type A, since a large quantity of the oocytes do not have the appearance of a complex with adequate granular and cytoplasm; in some cases they appear as rounded structures that apparently do not have cytoplasm that would be like an atretic oocyte, which in this study weren't taken into account for the analysis. This limitation meant that almost all the oocytes obtained were used for fertilization. In conditions in the field, it is necessary to use grade A, B, C oocytes to produce embryos, and it is possible to seek ways to correctly classify oocytes of this species.
Se demuestra que es un procedimiento seguro y reproducible, sólo se presentaron complicaciones en $1.7 \%$ de los casos, un edema que podría ser explicado como una reacción anafiláctica a la anestesia epidural utilizada, el cual se resolvió espontáneamente. Tampoco se presentaron complicaciones post aspiración como adherencias.

Se debe tener en cuenta que para obtener oocitos de animales jóvenes el tamaño del canal vaginal fue un limitante, ya que en 7 buvillas no se pudo pasar el transductor (datos no mostrados), es probable que en animales muy jóvenes, el paso del transductor lacere el canal vaginal y esos animales no se puedan aspirar. Se constató que 8 búfalas no pudieron ser aspiradas por razones anatómicas, debido a la estrechez de la vagina o adherencias de los órganos internos.

La tasa de obtención de oocitos en el presente trabajo fue de 8.07 oocitos/búfala por aspiración, la cual es superior a la informada en Italia 2.3 (13), Brasil 4.1-6.7 $(16,17)$ y 1.2 en India (18), una posible explicación podría ser el hecho que las aspiraciones fueron realizadas durante la estación reproductiva, mientras que algunos de estos autores muestran sus trabajos durante todo el año. La viabilidad en el presente estudio fue superior $(92 \%)$ a lo reportado en la literatura $(44 \%, 45 \%),(16,18)$.

Neglia et al (19), sugirieron que la longitud de la aguja y del sistema de succión tiene una gran influencia en la calidad de los oocitos encontrados, indicando que las células del cúmulus, pobremente adheridas se desprendan durante el proceso de aspiración. En este trabajo para la aspiración fue utilizada una aguja corta, que va directamente conectada al sistema de conducción, esta razón podría explicar la alta viabilidad de los oocitos obtenidos, más aún cuando uno de los principales parámetros de clasificación de los oocitos son las capas de granulosa que lo rodean.

También, es importante resaltar que al evaluar los oocitos son muy pocos los que se pueden clasificar como tipo A, debido a que una gran cantidad de oocitos no tienen la apariencia de un complejo con la granulosa y citoplasma adecuados; en algunos casos aparecen unas estructuras redondeadas que aparentemente no tienen citoplasma que semejarían un oocito atrésico que en este trabajo no fueron tenidos en cuenta para el análisis. Esta limitación hace que prácticamente todos los oocitos obtenidos sean utilizados para la fertilización. En las actuales condiciones de trabajo de campo, se hace necesario el uso de los oocitos grado A, B, C para producir embriones, cabe la posibilidad de buscar formas para la clasificación correcta de los oocitos en esta especie. 
It has been reported that a greater quantity of embryos are produced when oocytes collected from live animals are used for embryo production, rather than using ovaries from a slaughterhouse $(30.6 \pm 4.3 \%$ versus $18.5 \pm 1.8 \%)$. However, in literature consulted, no differences were observed in the maturation or cleavage of oocytes $(18,20)$ when comparing these two sources of oocytes.

Pregnancy rates obtained are superior to those reported by our group in 2011 ( $25 \%$ vs 29\%) although this difference is not significant and is in line with other reports in literature $(21,22)$.

Results obtained in this study using sexed semen differ from those reported by Lu et al (21), in which significant differences were observed in fertilization when sexed and conventional semen are used.

It is fundamental to understand that the production of blastocysts in vitro within a production system for in vitro embryos is not only influenced by biological factors, such as the development of follicles and the quality of oocytes, but also by factors related to laboratory procedures, the mother's nutrition and handling of the animals.

The use of frozen embryos for direct transfer facilitates establishing and managing these programs since in the properties where artificial insemination program are established, the only requirement that is needed is to change from inseminating to transferring the embryo, with time and luteal evaluation adjustments that an experienced technician can do without significantly increasing costs. From this experience, it can be said that with buffalo, biotechnological procedures that are performed with natural reproduction are successful. The pregnancy rate in this study was $29 \%$ compared with $20 \%$ (12) obtained when the receptors for transferring embryos were synchronized.

When the results of the program are analyzed from the point of view of the breeder based on the data reported here: 1.35 embryos are obtained by aspiration and a pregnancy rate of $29 \%$, resulting in the probability of pregnancy for each aspirated buffalo of $0.39 \%$, which means that three sessions of follicular aspiration should be done to guarantee at least one pregnancy for each animal that undergoes aspiration, calculating that to ensure at least one pregnancy 4 to 6 transferrable embryos should be produced per cycle (23). This means that for now, to see some improvement,
Se ha informado que se produce una mayor cantidad de embriones cuando se utiliza para la producción de embriones, oocitos colectados de animales vivos, que cuando se usan aquellos provenientes de ovarios de matadero (30.6 4 4.3\% versus $18.5 \pm 1.8 \%)$. No obstante, en la literatura colsultada no se observan diferencias ni en la maduración ni en el clivaje de los oocitos $(18,20)$, cuando se comparan las dos fuentes de oocitos.

Las tasas de preñez obtenidas, son superiores a las informadas por nuestro grupo en el año 2011 (25\% vs $29 \%$ ) (12) sin que esta diferencia sea significativa y están de acuerdo con otros informes en la literatura $(21,22)$.

Los resultados obtenidos en el presente estudio usando semen sexado, difieren de lo informado por Lu et al (21) en el cual se observaron diferencias significativas en la fertilización cuando se usa semen sexado y convencional.

Es fundamental entender que la producción de blastocistos in vitro, dentro de un sistema de producción de embriones in vitro, no está únicamente influenciada por factores biológicos, como el desarrollo de los folículos y la calidad de los oocitos, también por factores relacionados con los procedimientos de laboratorio, la nutrición de las madres y el manejo de los animales.

El uso de embriones congelados para transferencia directa, facilita el establecimiento y manejo de estos programas, debido a que en las explotaciones en las que están establecidos programas de inseminación artificial, lo único que se necesita es hacer el cambio de inseminar a transferir embrión, con los ajustes de tiempo y de evaluación luteal que un técnico experimentado puede realizar, sin incrementar significativente los costos. De la experiencia obtenida, se puede afirmar que con el búfalo, los procedimientos biotecnológicos que se realicen, complementados con la reproducción natural son exitosos. En este trabajo la tasa de preñez fue del $29 \%$ comparada con un $20 \%$ (12) obtenida cuando se sincronizaron las receptoras para la transferencia de los embriones.

Cuando se analizan los resultados del programa desde el punto de vista del criador basado en los datos aquí informados: se obtienen 1,35 embriones por aspiración y una tasa de preñez del 29\%, resultando una probabilidad de preñez por cada búfala aspirada del $0.39 \%$, lo que significa que se deberían hacer tres sesiones de aspiración folicular para poder garantizar por lo menos una preñez de cada animal que se somete a aspiración, calculando que para asegurar por lo menos una preñez deben ser producidos de 4 a 6 embriones transferibles por ciclo (23). Esto hace que por 
aspiration should be done with a minimum of five donors. Investigators should strive to improve embryo production conditions and analyze donors in order to increase the possibilities of generating embryos for the improvement program.

\section{Acknowledgements}

Inversiones Colbúfalos SAS, where the procedures with animals were done. ahora, para lograr algún mejoramiento, los trabajos de aspiración se deberían realizar con un mínimo de cinco donadoras. Los investigadores deben dedicarse a mejorar las condiciones de producción de embriones y a analizar las donadoras con el fin de incrementar las posibilidades de generar embriones para el programa de mejoramiento.

\section{Agradecimientos}

Inversiones Colbúfalos SAS, empresa donde se llevaron a cabo los procedimientos con los animales

\section{REFERENCES}

1. Cerón-Muñoz M, Gómez-Arroyave F, Ramírez-Toro J, Cifuentes $T$ y GutiérrezMolina S. Parámetros genéticos para la producción de leche, grasa y proteína en búfalos de Colombia. Livestock Research for Rural Development. 2012 24(2), Article \#30 URL Disponible en: http://www.Irrd. org/lrrd24/2/cero24030.htm

2. Perera B. Reproductive cycles of buffalo. Anim Reprod Sci 2011; 124(3):194-9.

3. Berdugo Gutiérrez J. Historia de la aplicación de biotecnologías reproductivas en la cría del búfalo en Colombia. Unipluri/versidad 2013;12(3):87-91. URL Disponible en: http://aprendeenlinea.udea. edu.co/revistas/index.php/unip/article/ viewFile/15160/13204

4. Drost M. Advanced reproductive technology in the water buffalo. Theriogenology 2007;68(3):450-3.

5. Boni R, Roviello S, Gasparrini B, Langella $M$, Zicarelli $L$. In vitro production of buffalo embryos in chemically defined medium. Buffalo J 1999;15:115-20.

6. Galli C, Duchi R, Crotti G, Lazzari G. Embryo production by ovum pick up in water buffalo. Theriogenology 1998; 49(1):400.

7. Kumar A, Solanki V, Jindal S, Tripathi V, Jain G. Oocyte retrieval and histological studies of follicular population in buffalo ovaries. Anim Reprod Sci 1997; 47(3):189-95.
8. Baruselli $P$, Mucciolo R, Visintin J, Viana W, Arruda R, Madureira E, et al. Ovarian follicular dynamics during the estrous cycle in buffalo (Bubalus bubalis). Theriogenology 1997; 47(8):1531-47.

9. Aspilcueta-Borquis RR, Sesana RC, Berrocal MHM, Seno LdO, Bignardi AB, El Faro L, et al. Genetic parameters for milk, fat and protein yields in Murrah buffaloes (Bubalus bubalis Artiodactyla, Bovidae). Genet Mol Biol 2010; 33(1):71-7.

10. Galeazzi P, Mercadante M, Silva J, de Albuquerque L, de Camargo G, Tonhati $\mathrm{H}$. Analysis of culling probability in dairy buffalo using survival models. Animal. 2010; 4(8):1325-9.

11. Hernández C, Castañeda S, Lopez C, Arias C, Watanabe Y, Berdugo J. Aspiración folicular guiada por ultrasonido (OPU) y producción de embriones in vitro en búfalas de agua (Bubalus bubalis) en el trópico bajo colombiano. Rev Colomb Cienc Pecu 2009; 22(3):567.

12. Galli C, Berdugo J, Pacheco L, Angel A, Posada I, Lazzari G, et al. First pregnancies obtained after transfer frozen-thawed buffaline embryos produced in Vitro in Colombia. Reprod Fertil Dev 2011; 24:190.

13. Di Francesco $S$, Novoa MVS, Vecchio $D$, Neglia G, Boccia L, Campanile G, et al. Ovum pick-up and in vitro embryo production (OPU-IVEP) in Mediterranean Italian buffalo performed in different seasons. Theriogenology 2012; 77(1):148-54. 
14. Sharma GT, Dubey PK, Nath A, Saikumar G. Co-culture of buffalo (Bubalus bubalis) preantral follicles with antral follicles: a comparative study of developmental competence of oocytes derived from in vivo developed and in vitro cultured antral follicles. Zygote. 2013; 21(3):286-94.

15. Parrish JJ, Susko-Parrish JL, LeibfriedRutledge ML, Critser ES, Eyestone WH, First NL. Bovine in vitro fertilization with frozen-thawed semen. Theriogenology $1986 ; 25: 591-600$.

16. Mondadori RG, Santin TR, Fidelis AAG, da Silva JS, Rumpf R, Báo SN. Ultrastructure of in vitro oocyte maturation in buffalo (Bubalus bubalis). Zygote 2010; 18(4):309-14.

17. Sá Filho M, Carvalho N, Gimenes L, TorresJúnior J, Nasser L, Tonhati H, et al. Effect of recombinant bovine somatotropin (bST) on follicular population and on in vitro buffalo embryo production. Anim Reprod Sci 2009; 113(1):51-9.

18. Manjunatha B, Ravindra J, Gupta P, Devaraj $M$, Nandi S. Oocyte recovery by ovum pick up and embryo production in river buffaloes (Bubalus bubalis). Reprod Domest Animal 2008; 43(4):477-80.
19. Neglia G, Gasparrini B, Caracciolo di Brienza V, Di Palo R, Campanile G, Antonio Presicce $G$, et al. Bovine and buffalo in vitro embryo production using oocytes derived from abattoir ovaries or collected by transvaginal follicle aspiration. Theriogenology 2003; 59(5):1123-30.

20. Gasparrini B, Sayoud H, Neglia G, Matos DGd, Donnay I, Zicarelli L. Glutathione synthesis during in vitro maturation of buffalo (Bubalus bubalis) oocytes: effects of cysteamine on embryo development. Theriogenology 2003; 60(5):943-52.

21. Lu Y, Liang $X$, Zhang M, Wang W, Kitiyanant $Y$, Lu S, et al. Birth of twins after in vitro fertilization with flow-cytometric sorted buffalo (Bubalus bubalis) sperm. Anim Reprod Sci 2007; 100(1):192-6.

22. Galli C, Duchi R, Colleoni S, Lagutina I, Lazzari G. Ovum pick up, intracytoplasmic sperm injection and somatic cell nuclear transfer in cattle, buffalo and horses: from the research laboratory to clinical practice. Theriogenology. 2014;81(1):138-51.

23. Bó GA, Baruselli PS, Chesta PM, Martins CM. The timing of ovulation and insemination schedules in superstimulated cattle. Theriogenology 2006; 65(1):89-101. 